\title{
Effect of High-Concentrated Bleaching Agents on the Bond Strength at Dentin/Resin Interface and Flexural Strength of Dentin
}

\author{
Cleusa VIEIRA \\ Yara T. Correa SILVA-SOUSA \\ Nelize Marcelino PESSARELLO \\ Fuad Abi Jaccob RACHED-JUNIOR \\ Aline Evangelista SOUZA-GABRIEL
}

Dental School, University of Ribeirão Preto, Ribeirão Preto, SP, Brazil

\begin{abstract}
This study evaluated the effect of bleaching agents on bond strength at the dentin/resin interface and the flexural strength of dentin. Forty maxillary canines were selected for the study. In the shear strength test, 40 slabs of intracoronary dentin $(5 \mathrm{x} 5 \mathrm{~mm}) \mathrm{obtained}$ from buccal surfaces of the crowns were included in acrylic resin. In the flexural strength test, 40 dentin bars $(8 \times 2 \times 2$ mm $)$ were obtained from the roots. The 40 hemi-sections of the lingual surface were prepared for scanning electron microscopy (SEM). The specimens were divided into 4 groups according to the bleaching protocol $(\mathrm{n}=10)$ : Unbleached (control), Sodium perborate $+20 \%$ hydrogen peroxide (SP $+20 \% \mathrm{HP}), 37 \%$ carbamide peroxide $(37 \% \mathrm{CP})$ and $38 \%$ hydrogen peroxide (38\% HP). After 7 days, the bond strength specimens were restored and tested. Dentin bars were bleached and subjected to a three-point bending test. Data (MPa) were analyzed by ANOVA and Tukey's test $(\alpha=0.05)$. In the shear test, the control group was superior $(p<0.05)$ to the bleached groups, which, in turn, were statistically similar $(\mathrm{p}>0.05)$. In the flexural strength test, the control group also had the highest values and differed significantly from the other groups $(\mathrm{p}<0.05)$. SEM revealed smear layer in all groups, with fissures in the bleached specimens. SP $+20 \% \mathrm{HP}$ and $38 \%$ HP showed discontinuous interfaces with few tags. In conclusion, bond strength of restorative material to dentin and flexural strength of dentin were reduced after the use of high-concentration bleaching agents.
\end{abstract}

Key words: adhesion, flexural strength, bleaching and dentin.

\section{INTRODUCTION}

In a non-vital tooth, crown darkening due to pigments incorporated into tooth structure it a common occurrence (1). The removal of the dark pigments can be performed by tooth bleaching because this is a minimally invasive intervention as compared with direct and indirect veneers and, if performed correctly, bears only minimal risks $(2,3)$. Bleaching is achieved from an oxi-reduction reaction in which reactive oxygen species and some free radicals released from bleaching agent degradation attack the long-chained, dark-colored chromophore molecules present in the dental tissues and break them down into smaller, less colored and more diffusible molecules, producing the whitening effect $(1,4)$. Due to its reactive properties, peroxides are the main active chemical component of most agents used in tooth bleaching therapies (2).

Hydrogen peroxide $\left(\mathrm{H}_{2} \mathrm{O}_{2}\right)$ is a strong caustic oxidizer at high concentrations $(>30 \%)(1,2)$. Because of its low molecular weight, this substance can penetrate dentin and can release oxygen that breaks the double bonds of the organic and inorganic compounds inside the dentinal tubules $(1,5)$. It can be used in its pure form or as the final product of the degradation of other bleaching substances, such as carbamide peroxide and sodium perborate (6-8).

Carbamide peroxide $\left[\mathrm{CO}\left(\mathrm{NH}_{2}\right)_{2} \mathrm{H}_{2} \mathrm{O}_{2}\right]$ is an organic compound containing approximately hydrogen peroxide and urea (9). Urea has an important role in raising the $\mathrm{pH}$ and also moves freely through the enamel and dentin $(6,10,11)$. Sodium perborate can be mixed with water instead of hydrogen peroxide. Sodium perborate is a sodium salt of the acid perboric available 
as a powder (6). It is stable when dry; however, in the presence of acid or water, it breaks down to form sodium metaborate, hydrogen peroxide, and nascent oxygen (7). In the "walking bleach technique" sodium perborate is mixed with water or hydrogen peroxide and then inserted into the access cavity (1).

However, there has been much concern about the potential adverse effects of tooth bleaching agents. It has been demonstrated that the microhardness (12-14) and modulus of elasticity (13) of enamel and dentin are altered by bleaching agents. These events may be attributed to the reduction of enamel inorganic content and dentin organic content (15) as well as morphological alterations in the dental substrate $(3,8)$, which may affect the fracture strength of bleached teeth (16).

After bleaching treatment, restorations needs to be changed, in most cases, because the color is not clinically accepted with the color attained by the natural teeth (12). The residual peroxide and the oxygen have both been claimed as factors that affect the polymerization of the adhesive systems and composite resins $(8,17)$ and also increases microleakage of adhesive interface $(18,19)$.

There are few studies that evaluated the mechanical properties of dentin submitted to tooth bleaching $(15,16,20,21)$. Pobbe et al. (16) found that the fracture strength of teeth was reduced after three sessions of internal bleaching with $38 \%$ hydrogen peroxide. Other studies found a reduction of the flexural properties of dentin after bleaching $(20,21)$.

Considering the divergence of materials and techniques available to perform non-vital bleaching, it is important to determine the effect of hydrogen peroxide on structural integrity of dentin and to verify the influence of this oxidizing agent on the bond strength of restorative materials and mechanical properties of dentin. Therefore, the hypothesis tested in this ex-vitro study is that bleaching intracoronal dentin using high-concentrated agents (simulating an in-office nonvital bleaching technique) does not affect composite bond strength to dentin or dentin flexural properties. Additionally, it was carried out a scanning electron microscopy (SEM) analysis of the adhesive interface and dentin surface after the bleaching treatments.

\section{MATERIAL AND METHODS}

The study protocol was approved by the local Ethics Committee (084/2010). Maxillary human incisors stored in steam of $0.1 \%$ thymol solution at $4^{\circ} \mathrm{C}$ were washed in running water for $24 \mathrm{~h}$ to eliminate thymol residues. Teeth were examined under a $\times 20$ magnifier (Leica Microsystems, Wetzlar, Germany), discarding those with structural defects. Forty teeth were selected.

Roots were sectioned $1 \mathrm{~mm}$ below the cementoenamel junction. Crowns were fixed in wax bisected longitudinally in mesiodistal direction using a double-faced diamond disk (KG Sorensen, Barueri, SP, Brazil) mounted in a low-speed handpiece (Dabi Atlante, Ribeirão Preto, SP, Brazil). Each crown half was sectioned in incisal, mesial, distal, and cervical faces to obtain square samples with 5-mm width and 5 -mm high $\left(25 \mathrm{~mm}^{2}\right)$, thus providing 80 fragments (40 for buccal face and 40 for lingual face).

\section{Bond Strength of Restorative Material to Dentin}

Forty fragments of vestibular face of crown were embedded in autopolymerized acrylic resin (Jet Classic, São Paulo, SP, Brazil) surrounded by a polyvinyl chloride (PVC) cylinder $(1.5-\mathrm{cm}$ diameter and $1.5-\mathrm{cm}$ high) with the intracoronary dentin faced up. After resin polymerization, the PVC cylinder was removed and the dentin surface was ground with \#280- and \#400-grit silicon carbide ( $\mathrm{SiC}$ ) paper (Norton, Lorena, SP, Brazil) under water cooling to flat the surface. Complementary grinding was performed with \#1200-grit $\mathrm{SiC}$ paper for $1 \mathrm{~min}$ to produce a standardized smear layer. The specimens were washed with $10 \mathrm{~mL}$ of $1 \%$ sodium hypochlorite to simulate the irrigation during biomechanical preparation of the root canals.

The specimens were randomly assigned to 4 groups ( $\mathrm{n}=10)$, according to the bleaching agent used: GI: Control (no bleaching); GII: sodium perborate $+20 \%$ hydrogen peroxide (Whiteness Perborato; Dentscare Ltda., Joinville, SC, Brazil); GIII: 37\% carbamide peroxide (Whiteness Super; Dentscare Ltda.) and GIV: 38\% hydrogen peroxide (Opalescence Boost PF; Ultradent Products Inc., South Jordan, UT, USA).

The specimens of GI (control) were stored at $37^{\circ} \mathrm{C}$, covered with gauze soaked in artificial saliva (Daterra, Ribeirão Preto, SP, Brazil) during the experimental period that preceded the shear strength test. The artificial saliva was changed every 2 days.

The dentin bleaching protocols performed in GII, GIII and GIV followed the recommendations of each respective manufacturer. In GII, the specimens were bleached with sodium perborate paste prepared with 2 parts of powder and a drop of $20 \%$ hydrogen peroxide. 
Immediately after preparation, the paste was applied on intracoronary dentin and the surface was covered by a temporary sealer (Coltosol; Vigodent, Rio de Janeiro, RJ, Brazil). Two bleaching sessions were performed with (a single application on each section) with an interval of 4 days between sessions, simulating the walking bleaching technique. During the interval, the specimens were stored at $37^{\circ} \mathrm{C}$, covered with gauze soaked in artificial saliva.

The GIII was bleached with $37 \%$ carbamide peroxide gel (Whiteness Super) and GIV was bleached with 38\% hydrogen peroxide gel (Opalescente). In both groups, two applications of the bleaching gel (10 min each) were done on dentin surface. After the 2 applications, the gel was completely removed from the surface with moist gauze and covered with temporary cement. The specimens were then stored at $37^{\circ} \mathrm{C}$, covered with gauze soaked in artificial saliva for 7 days. After this period, a new bleaching session was performed as described above.

After 7 days, the temporary cement was removed, dentin surface was conditioned with $35 \%$ phosphoric acid for $15 \mathrm{~s}$, washed with air/water spray and dried with absorbent paper. Conventional adhesive system (Adper Single Bond; 3M ESPE, St. Paul, MN, USA) was used according to the manufacturer's instructions. Restorative procedure was done using a split Teflon matrix $(3 \times 3 \times$ $4 \mathrm{~mm}$ ). An increment of Z250 Filtek resin (3M ESPE) was placed and the material was polymerized for $20 \mathrm{~s}$ using a light-curing unit (Dabi Atlante). Sequentially, the matrix was carefully opened, leaving a resin rectangle adhered to the dentin surface. A complementary 20 -s light curing cycle was accomplished to ensure that material was adequately polymerized.

The specimens were maintained in relative humidity at $4^{\circ} \mathrm{C}$ for $24 \mathrm{~h}$ and, after this period, they were subjected to shear bond test in a universal testing machine (Instron 4444; Instron Corporation, Canton, MA, USA) at a $0.5-\mathrm{mm} / \mathrm{min}$ cross-head speed and a $2-\mathrm{kN}$ load cell until the restoration displacement. Shear bond strength values were registered in $\mathrm{kN}$ and transformed in $\mathrm{MPa}$.

Failure modes at the resin/dentin interface were analyzed under a stereoscopic microscope at $\times 40$ magnification (Leica Microsystems, Wetzlar, Germany), and displayed as percent values. Failure was considered adhesive if it occurred at the dentin/adhesive interface, cohesive if it occurred in the material or the substrate, and mixed if it involved both the interface and the material.

Flexural Strength of Dentin
The roots of maxillary canines not used in the bond strength test were longitudinally sectioned using a diamond disc in mesiodistal direction. Forty dentin bars ( $8 \mathrm{~mm}$ long x $2 \mathrm{~mm}$ wide x $2 \mathrm{~mm}$ thick) were obtained from the cervical area of the buccal portion of roots. Dimensions were checked with a digital caliper (Digimess, São Paulo, SP, Brazil).

The specimens were randomly divided into the same 4 groups $(\mathrm{n}=10)$ described the bond strength test. The bleaching gel was applied on the face corresponding to the inner surface of the roots. The bleaching protocols were performed as described for bond strength test. The specimens were covered with gauze soaked in artificial saliva and stored at $37^{\circ} \mathrm{C}$ for $24 \mathrm{~h}$ until the flexural test.

The three-point bending flexural test was carried out in universal testing machine (Instron 4444), following the specifications of the ISO 178:2003 standard (1). A metallic device attached to Instron machine was specially developed for this test. This device fixed the distance between the center support points in $8 \mathrm{~mm}$ and fits the dimensions of the specimen. The load cell was applied perpendicular to the long axis of the specimen with a $0.5 \mathrm{~mm} / \mathrm{min}$ crosshead speed until fracture. The flexural strength $(\sigma f)$ of dentin was calculated using the following equation: $=\sigma_{\mathrm{f}}=3 F_{\max } L / 2 \mathrm{bd}^{2}$ being, $F_{\max }$ the maximum load in Newton, $L$ the distance between the support points in $\mathrm{mm}$ (standardized in $8 \mathrm{~mm}$ ), $b$ the specimen wide (standardized in $2 \mathrm{~mm}$ ) and $d$ the specimen thickness (standardized in $2 \mathrm{~mm}$ ).

\section{SEMAnalysis of Dentin Surface and Adhesive Interface}

The hemi-sections of the lingual surface of the crowns were subjected to the same bleaching protocols described for the mechanical tests. Five specimens of each group were prepared for the analysis of dentin surface and the other 5 for the analysis of adhesive interface.

For surface analysis, the specimens were cleaned ultrasonically with distilled water, gently air dried, stored at $37^{\circ} \mathrm{C}$ for $24 \mathrm{~h}$, and then sequentially dehydrated in ascending grades of ethanol $(25,50,75$, and 95 degrees for $20 \mathrm{~min} / \mathrm{each}$, and 100 degrees for $60 \mathrm{~min}$ ).

For the interface analysis, the specimens were restored with phosphoric acid, Single Bond adhesive system and Z250 Filtek resin. After the restoration, the specimens were individually placed on a precision cutting machine (Isomet 1000; Buehler, Lake Bluff, IL, 
USA) with a water-cooled diamond saw (South Bay Technology, San Clement, CA, USA) and sectioned perpendicular to the dentin surface, obtaining three slices of 1-mm thick each. The slabs were ground with wet 400-1200-grit silicon carbide papers (Norton) and received additional wet polishing with 1.0 and $3.0 \mu \mathrm{m}$ alumina pastes.

The biological tissues preservation was accomplished with a $2.5 \%$ glutaraldehyde solution buffered with a $0.1-\mathrm{M}$ sodium cacodylate solution (Merck KGaA, Darmstadt, Germany), for $12 \mathrm{~h}$ at $4^{\circ} \mathrm{C}$, followed by rinsing in distilled water for $3 \mathrm{~min}$ and immersion in distilled water for $1 \mathrm{~h}$, with water change every 20 -min intervals. They were then dehydrated in ascending grades of ethanol. After that, the samples were demineralized in $\mathrm{HCl}$ for $30 \mathrm{~s}$ and deproteinized in $2 \%$ $\mathrm{NaOCl}$ for $10 \mathrm{~min}$ to observe the hybrid layer.

All samples were dried, mounted on aluminum stubs, placed in a vacuum chamber, and sputter-coated with a gold layer of $\sim 300 \AA$ (SCD 005; Bal-Tec AG, Balzers, Liechtenstein). They were observed under a field-emission scanning electron microscope (JEOL, JSM 5410, Tokyo, Japan) operating at $15 \mathrm{kV}$ in different magnifications.

\section{Statistical Analysis}

Averages and standard deviations of the mechanical tests (bond strength and flexural resistance)

Table 1. Means and standard deviations (MPa) of bond strength at dentin/restorative material and flexural strength of dentin after different tooth bleaching protocols.

\begin{tabular}{lcc}
$\begin{array}{l}\text { Bleaching protocol } \\
\text { of intracoronary } \\
\text { dentin }\end{array}$ & $\begin{array}{c}\text { Bond strength } \\
\text { of composite } \\
\text { material }\end{array}$ & $\begin{array}{c}\text { Flexural strength } \\
\text { of dentin }\end{array}$ \\
\hline $\begin{array}{l}\text { Unbleached } \\
\text { (control) }\end{array}$ & $10.87 \pm 5.50 \mathrm{a}$ & $142.41 \pm 46.79 \bullet$ \\
$\mathrm{SP}+20 \% \mathrm{HP}$ & $4.94 \pm 3.14 \mathrm{~b}$ & $57.18 \pm 22.63$ \\
& $5.37 \pm 3.84 \mathrm{~b}$ & $83.09 \pm 26.92$ \\
$37 \% \mathrm{CP}$ & & \\
$38 \% \mathrm{HP}$ & $6.06 \pm 2.31 \mathrm{~b}$ & $23.09 \pm 4.79$
\end{tabular}

$\mathrm{SP}=$ Sodium perborate $\mathrm{HP}=$ hydrogen peroxide $\mathrm{CP}=$ carbamide peroxide. Same letters or symbols indicate statistical similarity within columns $(\mathrm{p}<0.05)$. were calculated, and data were analyzed using one-way ANOVA. Multiple comparisons were done using TukeyKramer test at a 0.05-significance level (Instat Program; GraphPad Software, San Diego, CA, USA).

\section{RESULTS}

\section{Bond Strength and Flexural Strength}

Table 1 shows the mean and standard deviations (MPa) of bond strength at the dentin/restorative material and flexural strength of dentin after the different bleaching protocols.

For bond strength, the analysis of variance showed statistically significant differences $(p=0.0062)$ among the bleaching protocols. Tukey-Kramer test ascertained that the unbleached group (control) had the highest mean bond strength and differed significantly from the other groups $(p<0.05)$, which, in turn, were statistically similar among themselves $(p>0.05)$. The analysis of failure mode after the shear bond strength test revealed the predominance of mixed failure in the control group (unbleached). The specimens that received the bleaching treatment, regardless of the protocol, exhibited a predominance of adhesive failures (Table 2).

For flexural strength, the unbleached group (control) had the highest mean flexural strength, differing from the other groups $(\mathrm{p}<0.05)$. Sodium perborate + $20 \%$ hydrogen peroxide and $37 \%$ carbamide peroxide had intermediate values and were statistically similar to each other $(\mathrm{p}>0.05)$. Specimens bleached with $38 \%$ hydrogen peroxide exhibited the lowest flexural strength of dentin, statistically similar to those bleached with

Table 2. Failure modes in each group after shear bond strength test.

\begin{tabular}{lcccc}
\hline $\begin{array}{l}\text { Failure } \\
\text { mode }\end{array}$ & $\begin{array}{c}\text { Unbleached } \\
\text { (control) }\end{array}$ & $\begin{array}{c}\mathrm{SP}+ \\
20 \% \mathrm{HP}\end{array}$ & $37 \% \mathrm{CP}$ & $38 \% \mathrm{HP}$ \\
\hline Adhesive & 20 & 50 & 60 & 50 \\
Mixed & 60 & 40 & 30 & 40 \\
$\begin{array}{l}\text { Cohesive } \\
\text { (material) }\end{array}$ & 10 & 10 & 10 & 10 \\
$\begin{array}{l}\text { Cohesive } \\
\text { (substrate) }\end{array}$ & 10 & - & - & - \\
\hline
\end{tabular}

$\mathrm{SP}=$ Sodium perborate $\mathrm{HP}=$ hydrogen peroxide $; \mathrm{CP}=$ carbamide peroxide. 
sodium perborate $+20 \%$ hydrogen peroxide $(p>0.05)$.

\section{SEM Analysis}

The SEM analysis revealed the ultrastructural features of the dental substrate subjected to different high-concentration bleaching agents, and the aspect of the restorative material-bleached dentin interface.

The unbleached group (control) exhibited dentin surface covered by smear layer (Fig. 1A) differently from the dentin surface bleached with sodium perborate $+20 \%$ hydrogen peroxide and $37 \%$ carbamide peroxide, which presented smear layer covering the dentinal tubule entrances and some areas with fissures (Fig. 1B,C). Dentin bleached with 38\% hydrogen peroxide had smear layer obliterating the dentinal tubules and cracks in the entire surface of the specimens (Fig. 1D).

In the analysis of the dentin/material interface (Fig. 2 A-D), it was observed the presence of a continuous interface, without gaps and some resin tags within dentinal tubules for the unbleached specimens (Fig. 2A) and for those bleached with 37\% carbamide peroxide (Fig. 2C). In the group bleached with sodium perborate $+20 \%$ hydrogen peroxide, fewer tags and some areas of discontinuity at the interface dentin/material were observed (Fig. 2B). The dentin bleaching with $38 \%$ hydrogen peroxide resulted in no resin tags and discontinuity areas in the adhesive interface (Fig. 2D).

\section{DISCUSSION}

Bleaching of nonvital teeth is a relatively low-risk intervention to improve the esthetics of endodontically treated teeth (4). This study assessed the effect of different bleaching protocols on the shear bond strength of dentin/restorative material interface and also verified the flexural strength of bleached dentin.

The outcomes of this study reject the hypothesis that high-concentration bleaching agents do not affect negatively the bond strength of the restorative material
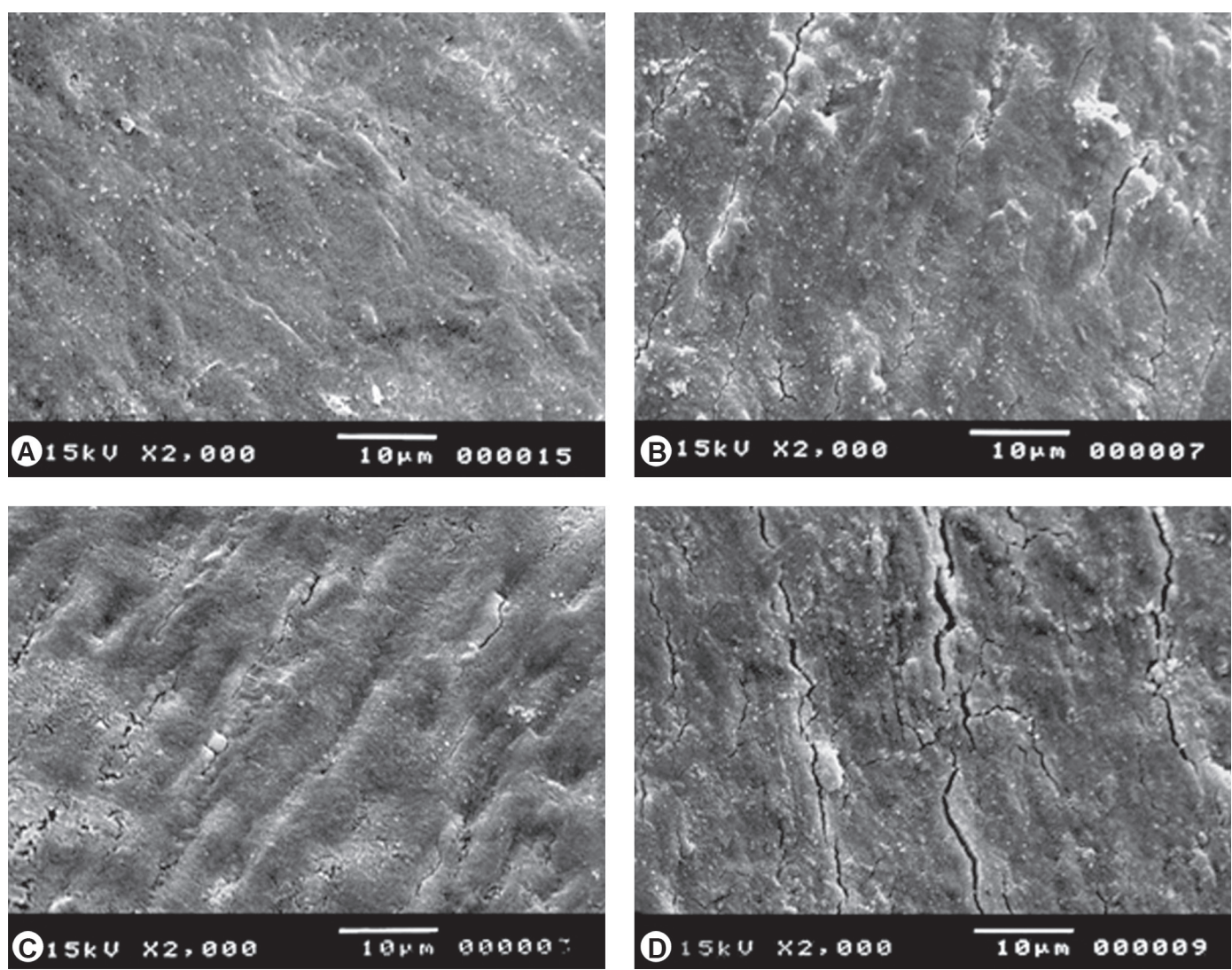

Figure 1. Dentin surface after the bleaching protocols: A) Unbleached (control) - smear layer covering the dentinal tubules; B and C) Sodium perborate $+20 \%$ hydrogen peroxide and $37 \%$ carbamide, respectively - smear layer covering the dentinal tubules and some areas with fissures and D) $38 \%$ hydrogen peroxide - smear layer obliterating the dentinal tubules and cracks in the surface. 
to dentin and the flexural strength of dentin. Lower bond strength values were obtained in the bleached groups, regardless of the bleaching agent compared with the unbleached group (control). This can be explained by the presence of $\mathrm{OH}^{-}$radicals, responsible for the bleaching effect of the tooth structure $(11,22)$. Because of its high oxidation potential, $\mathrm{OH}^{-}$radicals act in intertubular and peritubular dentin breaking the polypeptide chains and degrading components of connective tissue, particularly collagen and hyaluronic acid (21), thereby, attacking the organic component of dentin. These morphological alterations increase dentin permeability (23), reduce hardness $(13,14)$, which may be intensified by a higher exposure of dentin to the bleaching agent (16). Additionally, the shear bond strength might be reduced due to the presence of residual adhesive agents (8). Oxygen release can interfere in the penetration of resin into dentinal tubules, as well as to inhibit their polymerization $(17,18)$. To minimize the effect of residual oxygen in dentin tubules, an interval of 7 days before the resin restoration was conducted, as recommended by literature (18). However, it is believed that oxygen has not been fully released from dentin, because the surface was sealed with temporary cement, in the same way as occurs in clinical situations.

Analysis of failure mode after the bond strength test confirmed the results because the unbleached group (control) exhibited predominantly cohesive failure, demonstrating the higher strength at the bonding interface, as reported elsewhere (8). In the bleached groups, it was also observed a prevalence of the adhesive failure regardless of the bleaching procedure, emphasizing the fragility of the interface. Basting et al. (12) found a high percentage of adhesive failures in groups bleached with 10 and $22 \%$ carbamide peroxide.

SEM findings also corroborate the results of the bond strength test. The dentin surface subjected to the bleaching agents showed smear layer and cracks, especially in the specimens that received $38 \%$ hydrogen peroxide. The adhesive interface of groups bleached
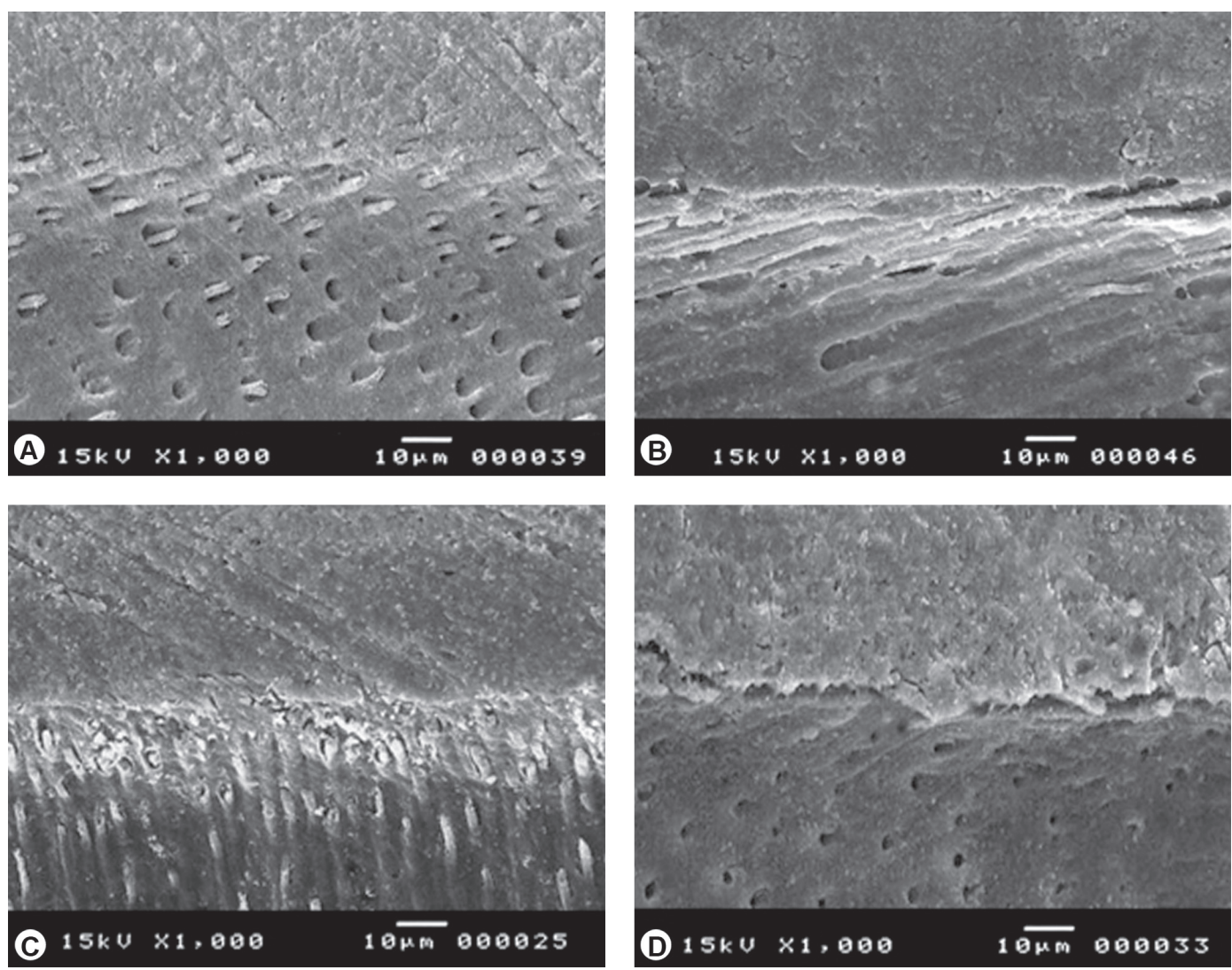

Figure 2. Bleached dentin/restorative material interface: $\mathrm{A}$ and $\mathrm{C}=$ Unbleached and bleached with $37 \%$ carbamide peroxide, respectively: presence of a continuous interface, without gaps and some resin tags within dentinal tubules; $\mathrm{B}=$ Sodium perborate $+20 \%$ hydrogen peroxide: few tags and some areas of discontinuity in the adhesive interface; and $\mathrm{D}=38 \%$ hydrogen peroxide: absence of resin tags and discontinuity areas in the interface. 
with sodium perborate/ hydrogen peroxide and hydrogen peroxide alone was discontinuous, with few or no resin tags, which might help understanding the lower bond strength of these groups. Ferreira et al. (8) also found few resin tags on the dentin interface bleached with $38 \%$ hydrogen peroxide and restored with the same restorative material used in this study.

Dental fracture in clinical use occurs from a large transitory force caused by an accident or a small force during repeated chewing (15). The flexural strength test can be used to examine these forces (24). In the present study, the specimens bleached with $38 \%$ hydrogen peroxide had the lowest flexural strength of dentin, similar to those bleached with sodium perborate combined with $20 \%$ hydrogen peroxide. The unbleached group had the highest flexural resistance.

The reduction in flexural strength of dentin (bleached and unbleached) can be justified by the same fact already mentioned for the bond strength, i.e., the strong degradation of the organic matrix caused by bleaching agents at high concentration (22). Rotstein et al. (25) reported that amount of calcium, phosphate, sulfur, and potassium of the hard tissue was affected by the bleaching agents, which indicated that inorganic portion of teeth was also compromised.

The difference in the results of the present study can be explained by the concentration of hydrogen peroxide present in each bleaching agent. The 38\% hydrogen peroxide is in the pure presentation form, therefore, has an intense oxidative power $(2,24)$. Sodium perborate was used in combination with $20 \%$ hydrogen peroxide. The $37 \%$ carbamide peroxide degrades into hydrogen peroxide (about 12\%) and urea (10). Thus, a greater decrease in bond strength was verified in the groups that received hydrogen peroxide at higher concentrations. Carrasco et al. (23) found an increase in dentin permeability when used $37 \%$ carbamide peroxide and sodium perborate combined with $20 \%$ hydrogen peroxide.

Overall, the findings of present study supports that bond strength of dentin/restorative material interface was reduced after tooth bleaching with high-concentrated bleaching agents. Flexural strength of dentin was reduced after tooth bleaching, and this effect was stronger with hydrogen peroxide at high concentration, with or without the sodium perborate.

Direct comparisons of the findings of this study with the literature could not be performed due to lack of studies that evaluated the flexural properties of dentin after the action of bleaching agents at high concentration. Ghavamnairi et al. (20) found a decrease in the flexural strength of bovine dentin submitted to bleaching with $20 \%$ carbamide peroxide. Zimmerman et al. (21) verified a reduction in dentin flexural modulus after bleaching with $38 \%$ hydrogen peroxide.

In the present study, bond strength of restorative material to dentin and flexural strength of dentin were reduced after the use of high-concentration bleaching agents. Although laboratory tests do not reproduce intraoral conditions, they offer a controlled environment for preparing and testing specimens to allow comparable evaluation of the variables under investigation. This study gives support to better understanding the interaction of bleaching agents on dental surface. However, other analytical methods should be assessed in future studies to gather more information about the impact of bleaching agents on dental hard tissues.

\section{RESUMO}

Este estudo avaliou o efeito de agentes clareadores na resistência de união da interface dentina/resina e resistência à flexão da dentina. Quarenta caninos superiores foram selecionados para o estudo. No teste de cisalhamento, 40 fragmentos de dentina intracoronária $(5 \times 5 \mathrm{~mm})$ obtidos a partir de superfícies vestibulares das coroas foram incluídos em resina acrílica. No teste de flexão, 40 barras de dentina $(8 \times 2 \times 2 \mathrm{~mm})$ foram obtidas a partir das raízes. As 40 hemi-seções da superfície lingual foram preparadas para microscopia eletrônica de varredura (MEV). Os espécimes foram divididos em 4 grupos de acordo com o protocolo de clareamento $(\mathrm{n}=10)$ : Não clareados (controle), perborato de sódio + peróxido de hidrogênio 20\% (PS + PH 20\%), peróxido de carbamida 37\% (PC37\%) e peróxido de hidrogênio 38\% (PH $38 \%$ ). Após 7 dias, as amostras destinadas à resistência de união foram restauradas e submetidas ao teste. As barras de dentina foram clareadas e submetidas ao teste de flexão de 3 pontos. Os dados (MPa) foram analisados por ANOVA e teste de Tukey $(\alpha=0,05)$. No teste de cisalhamento, o controle foi superior $(p<0,05)$ aos grupos clareados, que foram semelhantes entre si $(\mathrm{p}>0,05)$. Na resistência à flexão, o grupo controle também exibiu os maiores valores, diferente dos demais $(p<0,05)$. SEM revelou camada de smear em todos os grupos, com fissuras nos espécimes clareados. PS $+20 \%$ PH e PH $38 \%$ apresentaram interfaces de descontínuas com poucos tags. A resistência de união do material restaurador à dentina e a resistência à flexão da dentina foram reduzidas após o uso de agentes clareadores de alta concentração.

\section{REFERENCES}

1. Plotino G, Buono L, Grande NM, Pameijer CH, Somma F. Nonvital tooth bleaching: a review of the literature and clinical procedures. J Endod 2008;34:394-407.

2. Souza-Gabriel AE, Vitussi LO, Milani C, Alfredo E, Messias DC, Silva-Sousa YT. Effect of bleaching protocols with $38 \%$ hydrogen 
peroxide and post-bleaching times on dentin bond strength. Braz Dent J 2011;22:317-321.

3. Amaral C, Jorge A, Veloso K, Erhardt M, Arias V, Rodrigues JA. The effect of in-office in combination with intracoronal bleaching on enamel and dentin bond strength and dentin morphology. J Contemp Dent Pract 2008;9:17-24.

4. Rodrigues LM, Vansan LP, Pécora JD, Marchesan MA. Permeability of different groups of maxillary teeth after 38\% hydrogen peroxide internal bleaching. Braz Dent J 2009;20:303306.

5. Lima AF, Fonseca FM, Cavalcante AN, Aguiar FH, Marchi GM. Effect of the diffusion bleaching agents through enamel on dentin bonding at different depths. Am J Dent 2010;23:113-115.

6. Bonfante G, Kaizer OB, Pegoraro LF, Valle AL. Fracture resistance and failure pattern of teeth submitted to internal bleaching with $37 \%$ carbamide peroxide, with application of different restorative procedures. J Appl Oral Sci 2006;14: 247-252.

7. Souza-Zaroni WC, Lopes EB, Ciccone-Nogueira JC, Silva RCSP. Clinical comparison between the bleaching efficacy of $37 \%$ peroxide carbamide gel mixed with sodium perborate with established intracoronal bleaching agent. Oral Surg Oral Med Oral Pathol Oral Radiol Endod 2009;107:43-47.

8. Ferreira EA, Souza-Gabriel AE, Silva-Sousa YTC, Sousa-Neto MD, Silva RG. Shear bond strength and ultrastructural interface analysis of different adhesive systems to bleached dentin. Microsc Res Tech 2011;74:244-250.

9. Chuang SF, Chen HP, Chang CH, Liu JK. Effect of fluoridated carbamide peroxide gels on enamel microtensile bond strength. Eur J Oral Sci 2009;117:435-441.

10. Cavalli V, Shinohara MS, Ambrose W, Malafaia FM, Pereira PNR, Giannini M. Influence of intracoronal bleaching agents on the ultimate strength and ultrastructure morphology of dentine. Int Endod J 2009;42:568-575.

11. Barcellos DC, Benitti P, Fernandes VJR, Valera MC. Effect of carbamide peroxide bleaching gel concentration on the bond strength of dental substrates and resin composite. Oper Dent 2010;35:463-469.

12. Basting RT, Rodrigues AL, Serra MC. The effects of seven carbamide peroxide bleaching agents on enamel microhardness over time. J Am Dent Assoc 2003;134:1335-1342.

13. Pécora JD, Cruz Filho AM, Sousaneto MD, Silva RG. In vitro action of various bleaching agents on the microhardness of human dentin. Braz Dent J 1994;5:129-134.
14. Oliveira DP, Teixeira ECN, Ferraz CCR, Teixeira FB. Effect on intracoronal bleaching agents on dentin microhardness. J Endod 2007;33:460-462.

15. Berger SB, Pavan S, Vidal CD, Santos PH, Giannini M, BedranRusso AK. Changes in the stiffness of demineralized dentin following application of tooth whitening agents. Acta Odontol Scand 2012;70:56-60.

16. Pobbe POS, Viapiana R, Souza-Gabriel E, Marchesan MA, Sousa-Neto MD, Silva-Sousa YTC, et al.. Coronal resistance to fracture of endodontically treated teeth submitted to light-activated bleaching. J Dent 2008;36:935-939.

17. Shinohara MS, Peris AR, Pimenta LA, Ambrosano GM. Shear bond strength evaluation of composite resin on enamel and dentin after nonvital bleaching. J Esthet Restor Dent 2005;17:22-29.

18. Shinohara MS, Peris AR, Rodrigues JA, Pimenta LA, Ambrosano GM. The effect of nonvital bleaching on the shear bond strength of composite resin using three adhesive systems. J Adhes Dent 2004;6:205-209.

19. Rahimi S, Shahi S, Kimyai S, Khayyam L, Abdolrahimi M. Effect of calcium hydroxide dressing on microleakage of composite restorations endodontically treated teeth subsequent to bleaching. Med Oral Patol Oral Cir Bucal 2010;1:413-416.

20. Ghavamnairi M, Abedini S, Mehdizadeh-Tazangi A. Effect of different time periods of vital bleaching on flexural strength of the bovine enamel and dental complex. J Comtemp Dental Practice 2007;3:21-28.

21. Zimmerman B, Datko L, Cupelli M, Alapati S, Dean D, Kennedy M. Alteration of dentin-enamel mechanical properties due to dental whitening treatments. J Mech Behavior Bio Mat 2010;3:339-346.

22. Kawamoto K, Tsujimoto Y. Effects of the hydroxyl radical and hydrogen peroxide on tooth bleaching. J Endod 2004;30:45-50

23. Carrasco LD, Fröner IC, Corona SAM, Pécora JD. Effect of internal bleaching agents on dentinal permeability of non-vital teeth: quantitative assessment. Dent Traumatol 2003;19:85-89.

24. Plotino G, Grande NM, Bedini R, Pameijer CH, Somma F. Flexural properties of endodontic post and human root dentin. Dent Mat 2007:23:1129-1135.

25. Rotstein I, Dankner E, Goldman, A, Heling I, Stabholz A, Zalkind M. Histochemical analysis of dental hard tissues following bleaching. J Endod 1996;22:23-25.

Received August 1, 2011 Accepted November 11, 2011 